\title{
Hypopharyngeal Cancer pT1 TNM Finding v7
}

National Cancer Institute

\section{Source}

National Cancer Institute. Hypopharyngeal Cancer pT1 TNM Finding v7. NCI Thesaurus. Code C89032.

Hypopharyngeal cancer with tumor limited to one subsite of hypopharynx and/or $2 \mathrm{~cm}$ or less in greatest dimension. (from AJCC 7th Ed.) 